\title{
Effects of austempering temperature on microstructure and surface residual stress of carbidic austempered ductile iron $(\mathrm{CADI})$ grinding balls
}

\author{
Jin-hai Liu, Peng Xiong, *Bin-guo Fu, Wei-ting Yang, Xue-bo Zhao, Zi-ang Han, and Guo-lu Li
}

School of Materials Science and Engineering, Hebei University of Technology, Tianjin 300130, China

\begin{abstract}
The effects of austempering temperature on microstructure and surface residual stress of carbidic austempered ductile iron (CADI) grinding balls were systematically investigated in this work. The microstructures were oberserved by optical metallography and analyized by X-ray diffraction. The surface residual stress measured by the cutting method is mainly composed of thermal stress and phase transformation stress. The thermal stress in grinding balls was determined by ANSYS simulation technique, and the surface phase transformation stress was obtained by subtracting the simulated surface thermal stress from the measured surface residual stress. Results show that all microstructures consist of ausferrite, white-bright zones (mixture of martensite and austenite), nodular graphite, and carbides. The distribution of ausferrite shows uniform. With the increase of austempering temperature, the volume fraction and carbon content of austenite increase, whereas the amount of white-bright zone decreases. In addition, the surface residual stress increases with the increase of austempering temperature. Only the tension exists at the austempering temperature of $200{ }^{\circ} \mathrm{C}$, and the pressure exists at the austempering temperature of $220-260{ }^{\circ} \mathrm{C}$. The thermal stress changes from the tension on the inside with the radius of $0-35 \mathrm{~mm}$ to the pressure on the outside with the radius of $35-62.5 \mathrm{~mm}$, and the stress balance state presents at the radius of $35 \mathrm{~mm}$. It is also found that the transformation stress is related to the content of carbon-rich austenite, and will reduce by $5.03 \mathrm{MPa}$ accompanied with $1 \mathrm{vol} . \%$ increase of the austenite. The thermal compressive stress and the transformation tensile stress on the surface both decrease with the increase of the austempering temperature.
\end{abstract}

Key words: CADI grinding balls; austempering temperature; ANSYS; microstructure; residual stress

CLC numbers: TG143.5 Document code: A Article ID: 1672-6421(2018)03-173-09

$\mathrm{W}$ ith greater application of large diameter semiautogenous grinding (SAG) mill liners in the mining industry, a higher demand has been set for the quality of grinding balls ${ }^{[1]}$. At present, the forged steel ball is commonly used for SAG. However, it has disadvantages such as poor abrasive resistance and being out of round. Carbidic austempered ductile iron (CADI) is a relatively new kind of engineering material with superior properties, i.e. high strength, good impact toughness, superior wear resistance and impact fatigue property resistance ${ }^{[2-4]}$. CADI is gaining increasing attention in many areas, such as mining industry (liner, milling ball, sieve, etc.), engineering

\section{*Bin-Guo Fu}

Male, born in 1984, Ph.D. His research interests mainly focus on new types of abrasive materials such as $A D I$ and $C A D I$, and their forming technologies.

E-mail: fubinguohao@163.com

Received: 2017-12-11; Accepted: 2018-03-29

machinery, agricultural machinery, construction, railway, and defense structures ${ }^{[5-7]}$. Especially, in the mining industry, the replacement of the forged low alloy steel ball, and also the low and high chromium cast iron balls with the CADI grinding ball becomes a more and more obvious trend due to CADI grinding ball's excellent service qualities such as very low broken rate, strong circular shape preservation and high hardenability. In addtion, the advantages of low energy consumption and high grinding efficiency for SAG make the CADI grinding ball have a high cost performance $^{[8]}$.

The excellent wear resistance of the CADI grinding balls can be attributed to the ausferrite structure and the carbides ${ }^{[9,10]}$. The ausferrite structure can be obtained through the austempering process ${ }^{[11-13]}$, and it is composed of acicular ferrite and carbon-rich austenite ${ }^{[14,15]}$. However, the austempering process can introduce the residual stress. In addition, the austenite can be 
transformed into martensite in the impact condition which further leads to the stress within the CADI grinding ball ${ }^{[4]}$. As is known to all, the stress state of the grinding ball has a strong influence on its service span. Repeated drop tests of high chromium cast iron grinding balls was studied by Noguchi et al. and it was found that the residual tensile stress can lead to the ball breaking, spalling and poor abrasive resistance ${ }^{[16]}$. And Camurri et al. confirmed the fact that the cracks in the steel grinding ball would appear when the residual tensile stress is greater than the local failure resistance ${ }^{[17]}$. Unfortunately, to date, little attention has been paid to the residual stress of the CADI material. Therefore, it is necessary to investigate the residual stress of CADI grinding balls.

The state and distribution of the residual stress is complex and difficult to precisely calculate using only analytical methods, and the measurement position of residual stress is only limited to the surface of the material. According to the degree of damage, the surface residual stress test can be divided into non-destructive and destructive methods. However, a non-destructive method requires the sophisticated equipment and harsh testing environment. In the destructive method, the blind-hole method is more commonly used. However, the surface hardness of the grinding balls is high, which leads to drilling difficulties. Therefore, it would cause the redistribution of the stress, and the real values can not be obtained $^{[18]}$. The cutting method is a method for calculating the residual stress by releasing the stress at the measured point and measuring the released strain by a resistance strain gauge measurement technique. It is proved to be an accurate and inexpensive stress measurement technique for the grinding balls ${ }^{[19]}$. The residual stress is classified as thermal stress and phase transformation stress in this work since the grinding balls have not been used under working conditions, and it is difficult to distinguish them by an experimental method. Therefore, the thermal stress in grinding balls is determined by ANSYS simulation technique, and the surface phase transformation stress is studied by subtracting the simulated surface thermal stress from the measured surface residual stress.

The purpose of this work is to comprehensively investigate the effects of austempering temperatures on microstructure and surface residual stress of CADI grinding balls with a diameter of $125 \mathrm{~mm}$ by experiments and numerical simulation technique.

\section{Experimental procedures}

\subsection{CADI grinding balls preparation}

The chemical compositions of the CADI grinding balls are given in Table 1. Pig iron, steel scraps, ferrosilicon, ferromanganese,

Table 1: Chemical composition of CADI grinding balls (wt.\%)

$\begin{array}{lllllllll}\text { C } & \text { Si } & \mathrm{Mn} & \mathrm{Cr} & \mathrm{Cu} & \mathrm{P} & \mathrm{S} & \mathrm{Fe}\end{array}$

3.3-3.8 2.4-2.9 0.5-1.0 $0.6-0.9 \quad 0.5-0.7<0.06<0.03$ Bal. low carbon ferrochromium and copper sheet were used as the raw materials. The melting was carried out in a medium frequency induction furnace with a holding capacity of $0.5 \mathrm{t}$. The melt was held at $1,550{ }^{\circ} \mathrm{C}$ for $2 \mathrm{~min}$ and then poured into the casting ladle, the spheroidizing treatments were carried out by the cored-wire injection process. Thereafter, the treated molten iron was poured into the metal mold with a sand liner in cavity. Finally, four grinding balls with a diameter of $125 \mathrm{~mm}$ were obtained simultaneously, as shown in Fig. 1.

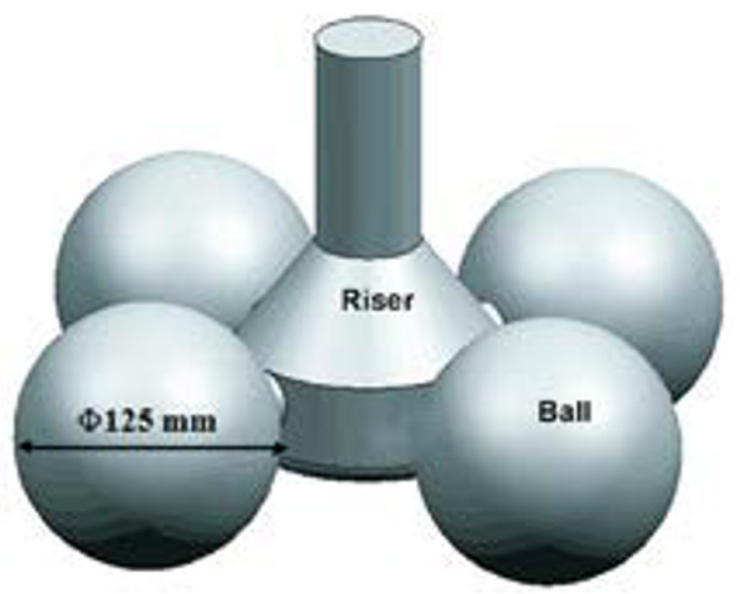

Fig. 1: Schematic diagram of cast grinding balls

Heat treatment was subsequently carried out. The grinding balls were initially austenitized at $920{ }^{\circ} \mathrm{C}$ for $3 \mathrm{~h}$, followed by quenching into molten salt bath $\left(50 \% \mathrm{KNO}_{3}+50 \% \mathrm{NaNO}_{2}\right)$. In order to obtain different supercooling and nucleation of ferrite, the grinding balls in the molten salt bath were kept for $20 \mathrm{~min}$ at different temperatures $\left(200,220,240,260{ }^{\circ} \mathrm{C}\right)$. The grinding balls were further treated at $260^{\circ} \mathrm{C}$ for $2.5 \mathrm{~h}$ in an electric resistance furnace to complete the isothermal transformation process. The detailed process parameters are shown in Table 2.

Table 2: Heat treatment process of CADI grinding balls

\begin{tabular}{cccccc}
\multicolumn{2}{c}{ Austenitizing } & \multicolumn{2}{c}{ Austempering } & \multicolumn{2}{c}{ Tempering } \\
$\begin{array}{c}\text { Temperature } \\
\left({ }^{\circ} \mathrm{C}\right)\end{array}$ & $\begin{array}{c}\text { Time } \\
\text { (h) }\end{array}$ & $\begin{array}{c}\text { Temperature } \\
\left({ }^{\circ} \mathrm{C}\right)\end{array}$ & $\begin{array}{c}\text { Time } \\
(\mathbf{m i n})\end{array}$ & $\begin{array}{c}\text { Temperature } \\
\left({ }^{\circ} \mathrm{C}\right)\end{array}$ & $\begin{array}{c}\text { Time } \\
(\mathbf{h})\end{array}$ \\
\hline & & 200 & & & \\
920 & 3 & 220 & 20 & 260 & 2.5 \\
& & 240 & 20 & & \\
& & 260 & & &
\end{tabular}

\subsection{Optical metallography and X-ray diffraction}

Microstructures of the as-cast and heat-treated specimens $(10 \mathrm{~mm} \times 10 \mathrm{~mm} \times 10 \mathrm{~mm})$ taken from the position of $10 \mathrm{~mm}$ away from the surface of the grinding balls were observed by optical microscopy (OM) after being etched with $4 \%$ nital solution. The amount of carbides was measured by OM and more than 10 micrographs (magnified 100×) were analyzed to obtain statistically average values. X-ray diffraction (XRD) analysis was performed to estimate the volume fraction and the carbon content of austenite. A monochromatic copper $\mathrm{K} \alpha$ 
radiation was employed at $40 \mathrm{kV}$ and $40 \mathrm{~mA}$. A Rigaku rotating head anode diffractometer was used to scan the angular $2 \theta$ ranging from $30^{\circ}$ to $100^{\circ}$ at a scanning speed of $3^{\circ} \cdot \mathrm{min}^{-1}$. The profiles were analyzed with Jade 5 software to obtain the peak positions and the integrated intensity of (111), (220) and (311) planes of austenite as well as (110) and (211) planes of ferrite. The volume fractions of ferrite and austenite were determined by the direct comparison method using the integrated intensities of (211) plane of ferrite and (220) plane of austenite ${ }^{[20]}$.

The carbon content of austenite was determined by equation (1) as follows ${ }^{[21]}$ :

$$
\alpha_{\gamma}=0.3548+0.00441 C_{\gamma}
$$

where $\alpha_{\gamma}$ is the lattice parameter of austenite, and $C_{\gamma}$ is the weight percentage of carbon in austenite.

\subsection{Thermal stress simulation and residual stress test}

The thermal stress of the CADI grinding balls after austempering was determined by a thermal-stress model developed in ANSYS. The ANSYS simulation process can be divided into cell type defintion, physical property parameters setting, geometric model and mesh creation, imposing a constraint, solving and calculating $^{[22]}$.

\subsubsection{Cell type definition}

Coupled-Field was used to simulate the thermal stress of CADI grinding balls due to the austempering thermal stress involving the heat and structure. Two-dimensional and four-node plane element (PLANE13) was used for a plane analysis with a key option [KEYOPT(4)] = 1 for defining cells shown in Fig. 2.

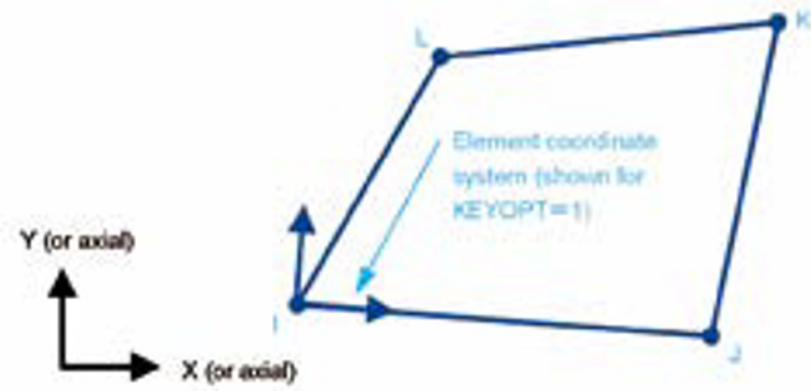

Fig. 2: Two-dimensional solid geometry model of PLANE13

\subsubsection{Physical property parameters setting}

The isotropic linear elastomeric model was selected in this experiment. The physical properties ${ }^{[23]}$ and heat transfer coefficient ${ }^{[24]}$ of the CADI material used in the simulation are given in Tables 3 and 4, respectively.

\subsubsection{Geometric model and mesh creation}

In this work, the $\Phi 125 \mathrm{~mm}$ workpiece was considered as a plane model, and the quadrilateral meshes were generated using
Table 4: Heat transfer coefficient of CADI grinding balls ${ }^{[24]}$

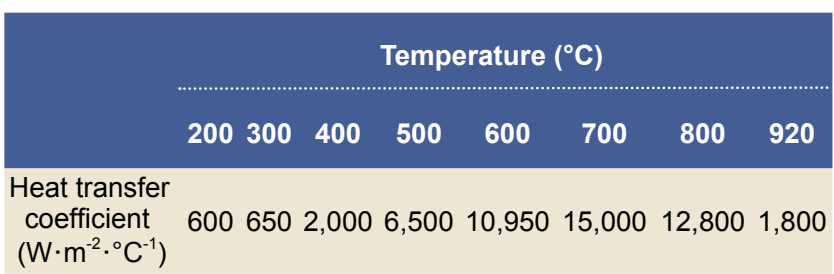

a mapping method. The mesh size of $2.5 \mathrm{~mm}$ can be selected to meet the process requirements and the unit division result is shown in Fig. 3.

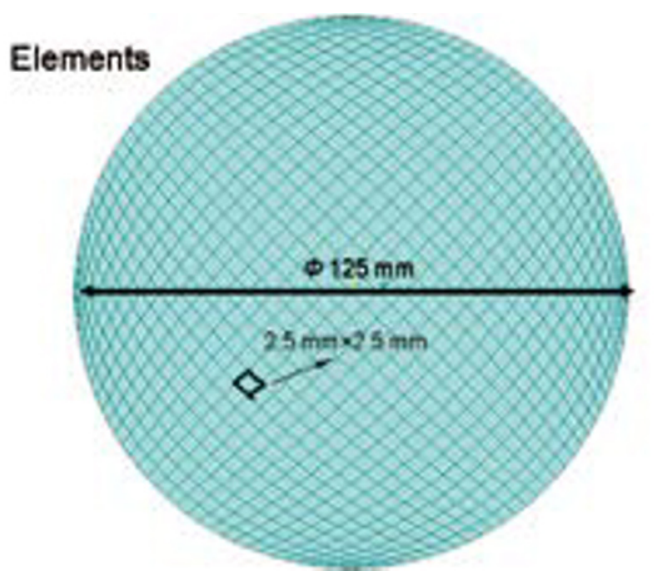

Fig. 3: Model of mesh division of CADI grinding ball

\subsubsection{Loads and solution}

The initial temperature considered for the CADI grinding ball was $920{ }^{\circ} \mathrm{C}$ (austenitizing temperature). On model edges, heat flux was imposed as linear convective law due to the contact between the grinding ball and the nitrate during the austempering process. The termination temperatures were selected as 200 , 220, 240 and $260{ }^{\circ} \mathrm{C}$ (austempering temperature), respectively. Moreover, the calculation time and step were chosen as 1,200 s (austempering time) and $10 \mathrm{~s}$, respectively. Then the processes of solution and calculation were started.

The calculation of temperature field is to solve the nonlinear transient heat conduction equation as follows:

$$
\frac{\partial}{\partial x}\left(\lambda \frac{\partial T}{\partial x}\right)+\frac{\partial}{\partial y}\left(\lambda \frac{\partial T}{\partial y}\right)+\frac{\partial}{\partial z}\left(\lambda \frac{\partial T}{\partial z}\right)+q^{\prime}=\rho c_{\mathrm{p}} \frac{\partial T}{\partial z}
$$

where $T$ is the temperature, $t$ is the time, $\lambda$ is the heat conductivity coefficient, $\rho$ is the density, $c$ is the mass heat capacity at constant pressure, $q^{\prime}$ is the inner heat source strength and its value is given in equation (3):

$$
q^{\prime}=\Delta H \frac{\partial V}{\partial t}
$$

where $V$ is the volume, $\Delta H$ is the latent heat of phase change per unit volume.

Table 3: Physical properties of CADI grinding balls ${ }^{[23]}$

\begin{tabular}{cccccc}
$\begin{array}{c}\text { Density } \\
\left(\mathbf{k g} \cdot \mathrm{m}^{-3}\right)\end{array}$ & $\begin{array}{c}\text { Specific heat capacity } \\
{\left[\mathrm{J} \cdot\left(\mathbf{k g} \cdot{ }^{\circ} \mathbf{C}\right)^{-1}\right]}\end{array}$ & $\begin{array}{c}\text { Thermal conductivity } \\
{\left[\mathbf{W} \cdot\left(\mathrm{m}^{\circ}{ }^{\circ} \mathrm{C}\right)^{-1}\right]}\end{array}$ & $\begin{array}{c}\text { Thermal expansion } \\
\text { coefficient }\left(\mathbf{1 0}^{-6} \cdot{ }^{\circ} \mathrm{C}^{-1}\right)\end{array}$ & $\begin{array}{c}\text { Young's modulus } \\
(\mathrm{GPa})\end{array}$ & Poisson's ratio \\
\hline 7,200 & 700 & 35 & 13 & 170 & 0.27 \\
\hline
\end{tabular}


The boundary condition for quenching process simulation is set according to equation (4):

$$
-k\left(\frac{\partial T}{\partial n}\right)_{s}=h_{\Sigma}\left(T_{\mathrm{s}}-T_{\mathrm{a}}\right)
$$

where $\partial T / \partial n$ is the temperature gradient of the outer-normal direction of boundary, $T_{\mathrm{s}}$ is the surface temperature of the grinding ball, $T_{\mathrm{a}}$ is the temperature of the quenching medium, $h_{\Sigma}$ is the comprehensive heat transfer coefficient.

The initial condition is that the temperature state is determined when the time is at $t=t_{0}$, and it can be described as follows:

$$
T(x, y, z, t=0)=T_{0}(x, y, z)
$$

After the temperature field analysis, the stress field was calculated by a thermal-stress model which follows Mises yield criterion. The detailed calculation results can be viewed by general post-processing (Post 1) and time post-processing (Post 26).

The cutting method was employed to measure the surface residual stress with a DH3815N-2 static strain test system. The first step was to paste a three-element strain gage rosette onto the surface of the grinding ball since the main stress direction was unknown. Then the measured part was separated from its adjacent to release the residual stress by wire-electrode cutting. The paste location of the three-element strain gage rosette and the sequence of the wire-electrode cutting $(1,2,3,4)$ are shown in Fig. 4. The three direction strain values $\left(\varepsilon_{0}, \varepsilon_{45}\right.$ and $\varepsilon_{90}$ ) could be transferred to the computer in real-time while the wire cutting was working. The released strain curve over cutting depth for the grinding ball can be seen in Fig. 5. It shows that after the cutting depth reached $10 \mathrm{~mm}$, the surface strain remained unchanged as the cutting depth continued to increase. This indicates that the surface stress released completely. The cutting depth was selected as $10 \mathrm{~mm}$ based on a great number of experiments, and the strain values were recorded when the temperature of the cutting position droped to room temperature.

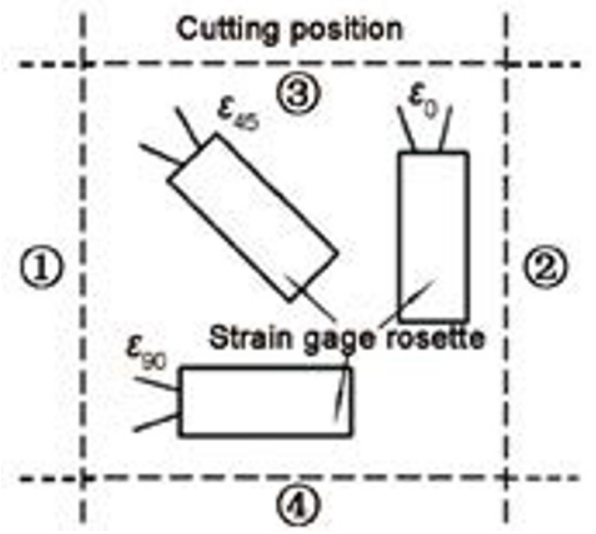

Fig. 4: Schematic diagram of cutting method

Finally all the strain values in each direction were superimposed and the residual stress could be calculated by equation $(6)^{[25]}$.

$\sigma_{1}, \sigma_{2}=-\frac{E}{2}\left\{\frac{\varepsilon_{0}+\varepsilon_{90}}{1-\mu} \pm \frac{1}{1+\mu} \times \sqrt{\left(\varepsilon_{0}-\varepsilon_{90}\right)^{2}+\left[2 \varepsilon_{45}-\left(\varepsilon_{0}+\varepsilon_{90}\right)\right]^{2}}\right\}$

where $\sigma_{1}$ and $\sigma_{2}$ are the residual stress of the $0^{\circ}$ and $90^{\circ}$

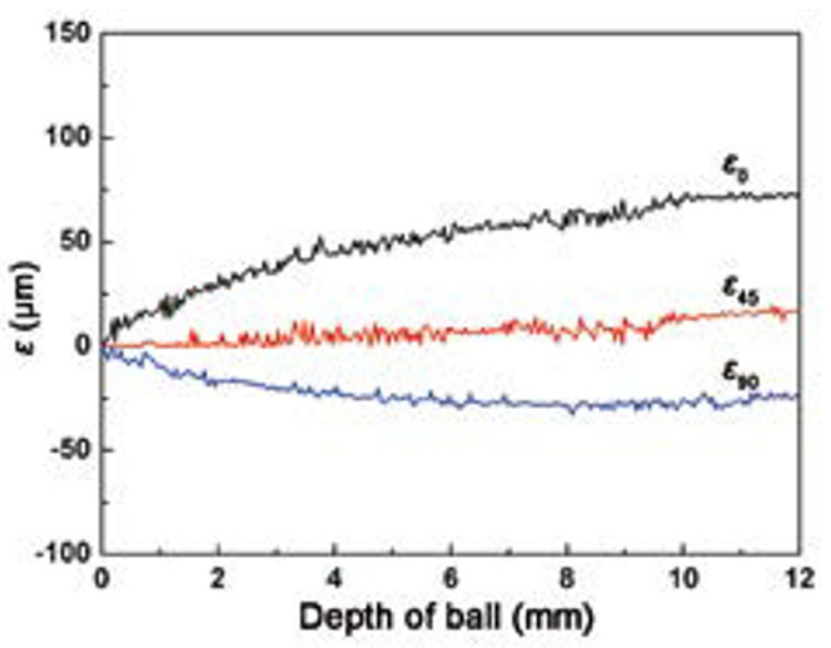

Fig. 5: Released strain curve over cutting depth for grinding ball

directions, respectively, $\varepsilon_{0}, \varepsilon_{45}$ and $\varepsilon_{90}$ are the strain values of the $0^{\circ}, 45^{\circ}$ and $90^{\circ}$ directions, $\mu$ is Poisson's ratio in this work $(\mu \approx 0.27$ ), $E$ is Young's modulus and $E \approx 170 \mathrm{GPa}$.

\section{Results and discussion}

\subsection{Microstructure}

The microstructure of as-cast sample is shown in Fig. 6, which shows that the microstructure mainly consists of the pearlite, nodular graphite, and carbides, and the amount of carbides is about 7vol.\%. Figure 7 shows the OM micrographs of the CADI grinding balls after austempering treatment. It shows that all the microstructures are composed of ausferrite (mixture of acicular ferrite and carbon-rich austenite), white-bright zones phase, nodular graphite, and carbides. The amount of carbides in the CADI sample is about $5 \mathrm{vol} . \%$, which is slightly less than that in the as-cast sample due to some carbides dissolving during the high temperature austenitization process. The ausferrite is mainly distributed around the nodular graphite (Fig. 7a), and its distribution becomes more uniform with the increase of austempering temperature (Figs. $7 \mathrm{a}-\mathrm{d}$ ). The white-bright zone consists of martensite and austenite microstructure and

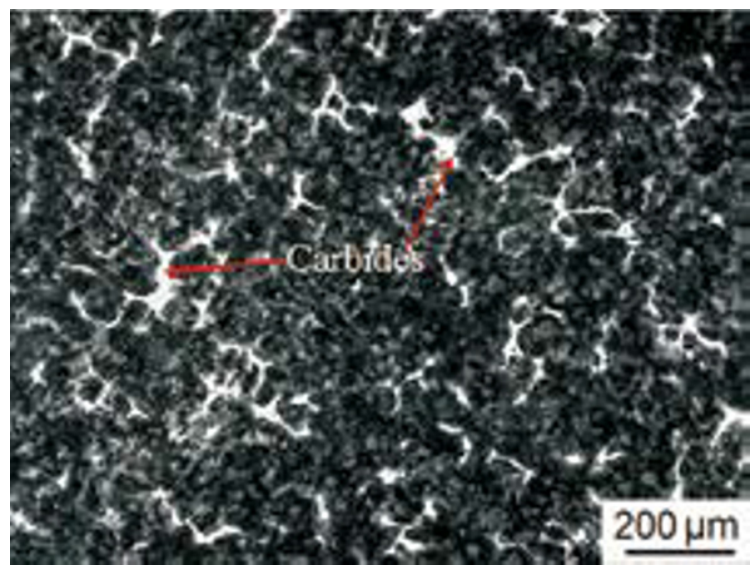

Fig. 6: Microstructure of as-cast grinding ball 

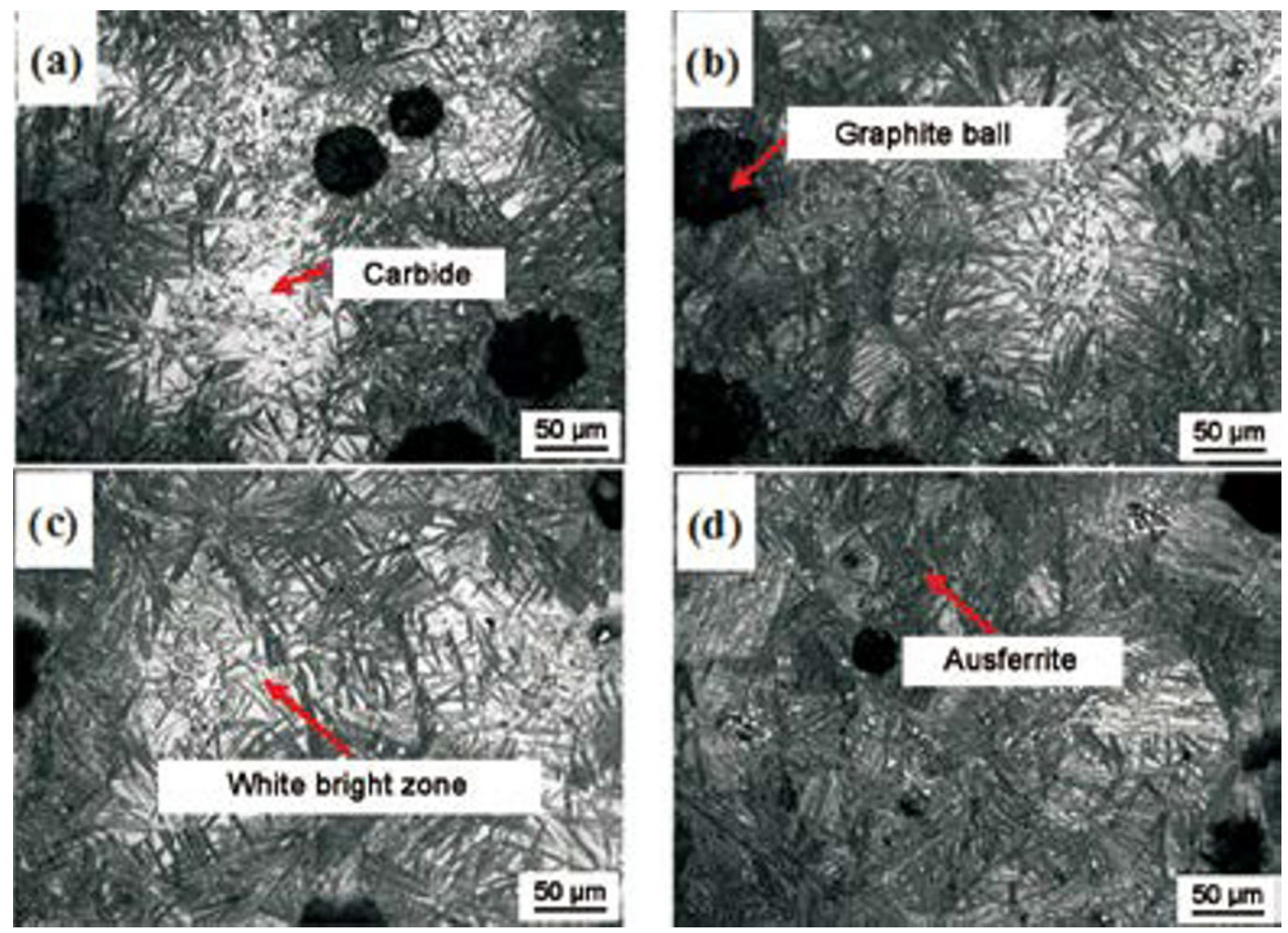

Fig. 7: Microstructures of CADI grinding balls with different austempering temperatures: (a) $200^{\circ} \mathrm{C}$; (b) $220^{\circ} \mathrm{C}$; (c) $240{ }^{\circ} \mathrm{C}$; (d) $260^{\circ} \mathrm{C}$

the result is in good agreement with that reported by Liu et al. ${ }^{[26]}$, which showed that the white-bright zone with martensite microstructure had a higher microhardness value. The amount of the white-bright zones gradually decreases with the increase of austempering temperature (Fig. 7d). As is known, the growth of acicular ferrite in ausferrite is dependent on the carbon concentration gradient at the interfaces between acicular ferrite and austenite ${ }^{[27,28]}$. The diffusion rate and distance of carbon atoms directly affect the growth rate of acicular ferrite ${ }^{[29]}$. When the grinding ball is austempered at a lower temperature, such as $200{ }^{\circ} \mathrm{C}$, the diffusion rate of carbon atoms is slower and the diffusion distance is limited. Accordingly, the content of carbon is higher in acicular ferrite and lower in austenite, which causes the austenite unstable. Therefore, the austenite is inclined to transform into the martensite rather than the ausferrite after the isothermal transformation, and finally forms the whitebright zone. With the increase of austempering temperature, the diffusion rate of carbon atoms is accelerated and the diffusion distance is increased. The carbon content of austenite increases and the austenite stability is enhanced accordingly. Thus the white-bright zone is reduced and the distrbution of ausferrite is more and more uniform.

The quantitative features of the microstructures are obtained through X-ray diffraction. Figure 8 shows the XRD spectrums of CADI grinding balls with different austempering temperatures. It can be observed that two kinds of phases are indexed as $\alpha$ phase with a bcc structure and $\gamma$ phase with a fcc structure. The volume fraction and the carbon content of austenite were calculated by quantitative analysis, and the results are shown in Fig. 9. The volume fraction of carbon-rich austenite can reach 31 vol.\% after being austempered at $260{ }^{\circ} \mathrm{C}$,

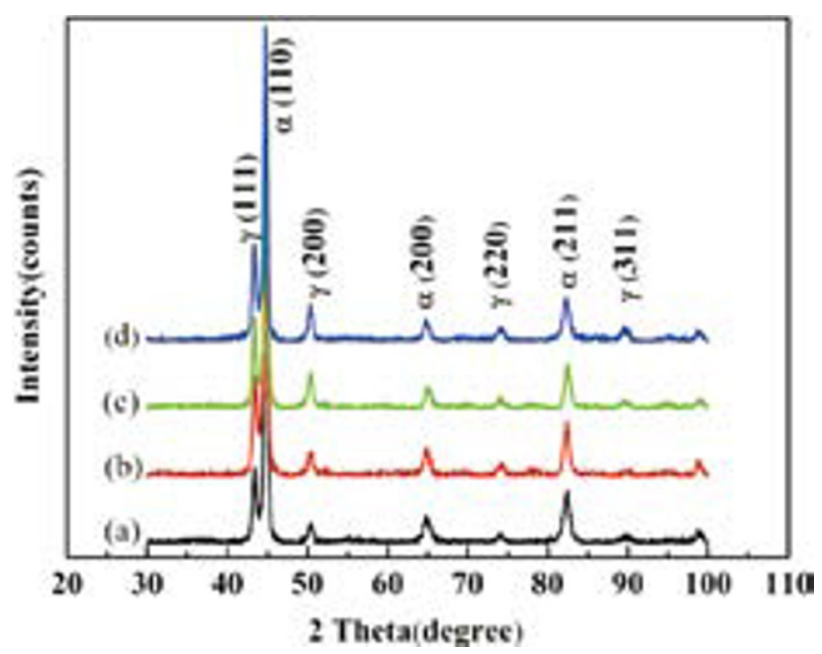

Fig. 8: XRD patterns of CADI grinding balls heat treated at different austempering temperatures: (a) $200^{\circ} \mathrm{C}$; (b) $220^{\circ} \mathrm{C}$; (c) $240{ }^{\circ} \mathrm{C}$; (d) $260^{\circ} \mathrm{C}$

which shows an increase about $72.2 \%$ than that austempered at $200{ }^{\circ} \mathrm{C}$. Meanwhile, the carbon content of austenite increases from $1.14 \mathrm{wt} . \%$ at $200{ }^{\circ} \mathrm{C}$ to $1.32 \mathrm{wt} . \%$ at $260{ }^{\circ} \mathrm{C}$. It can be seen that both the volume fraction and the carbon content of austenite increase with the austempering temperature increasing. Due to the low temperature (austempered at $200{ }^{\circ} \mathrm{C}$ ), the rate and the distance of carbon diffusion is limited. Therefore, the partial austenite is transformed to the martensite after the isothermal transformation and the volume fraction of carbon-rich austenite is lower. With the increase of austempering temperature, the incubation period of isothermal transformation become much shorter, and the amount of diffused carbon atoms across the interface between the ferrite and the austenite increases, which 


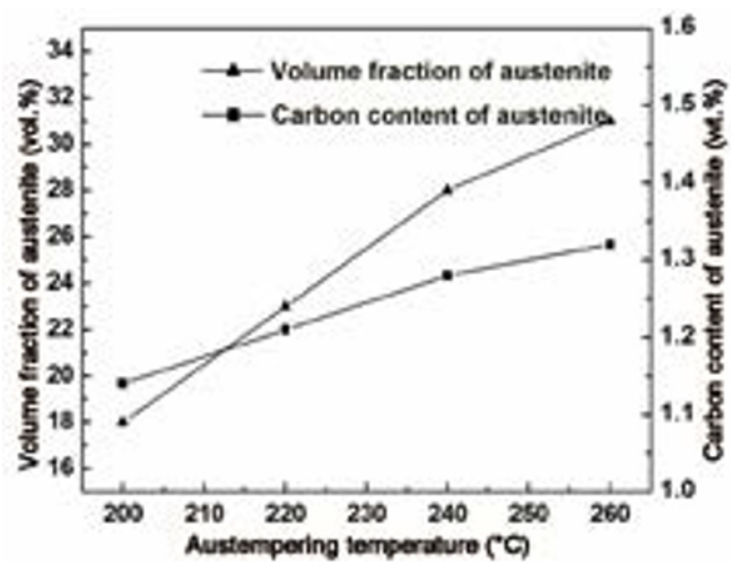

Fig. 9: Effect of austempering temperatures on volume fraction and carbon content of austenite in CADI grinding balls

lead to the decrease of carbon content in acicular ferrite and improve the stability of carbon-rich austenite. Accordingly, the amount of retained austenite increases.

\subsection{Surface residual stress of CADI grinding balls}

The surface residual stress of CADI grinding balls is mainly affected by thermal stress and phase transformation stress in this work. It can be described as follows:

$$
\sigma_{\mathrm{R}}=\sigma_{\mathrm{t}}+\sigma_{\mathrm{P}}
$$

where $\sigma_{\mathrm{R}}$ is surface residual stress, $\sigma_{\mathrm{t}}$ is surface thermal stress, $\sigma_{\mathrm{P}}$ is surface phase transformation stress.

According to the surface residual stress measurement method, the strain release of the CADI grinding balls after cutting are obtained and are shown in Table 5 . The strain value obtained by

Table 5: Release of surface strain of CADI grinding balls $\left(\times 10^{-6}\right)$ during experiment process

$\begin{array}{cccc}\begin{array}{c}\text { Austempering temperature } \\ \left({ }^{\circ} \mathrm{C}\right)\end{array} & \varepsilon_{0} & \varepsilon_{45} & \varepsilon_{90} \\ 200 & -50.58 & -59.34 & -66.15 \\ 220 & 47 & 58 & 78 \\ 240 & 112.15 & 62.20 & 36.24 \\ 260 & 126.2 & 81.38 & 72.90\end{array}$

the strain gage is the same as the surface of the grinding ball. However, the sign of the strain is the opposite. Therefore, when the stress is calculated, the resulting value should be multiplied by a negative sign. The residual stress on the surface of grinding ball can be calculated by equation (6) and the total residual stress $\left(\sigma_{\text {avg }}\right)$ are shown in Table 6 and Fig. 10. It can be seen

Table 6: Surface residual stress of CADI grinding balls during the experiment process

\begin{tabular}{cccc}
$\begin{array}{c}\text { Austempering temperature } \\
\left({ }^{\circ} \mathbf{C}\right)\end{array}$ & $\boldsymbol{\sigma}_{1}(\mathrm{MPa})$ & $\boldsymbol{\sigma}_{2}(\mathrm{MPa})$ & $\boldsymbol{\sigma}_{\text {avg }}(\mathrm{MPa})$ \\
200 & 12.5 & 14.6 & 13.6 \\
220 & -16.7 & -12.4 & -14.6 \\
240 & -22.6 & -12.0 & -17.3 \\
260 & -27.5 & -18.9 & -23.2 \\
\hline
\end{tabular}

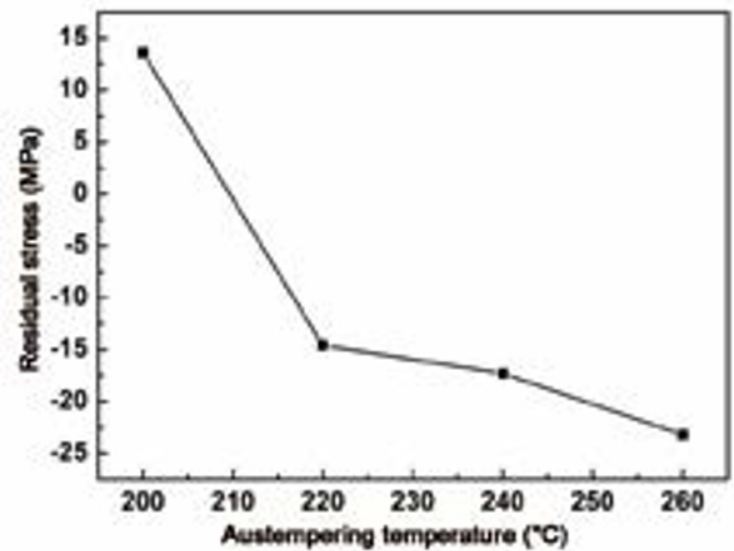

Fig. 10: Effect of austempering temperature on surface residual stress of CADI grinding balls

that the surface of the grinding ball exhibits the tensile stress with the value of $13.6 \mathrm{MPa}$ when the austempering temperature is $200{ }^{\circ} \mathrm{C}$. The surface residual stress changes from the tensile stress to the compressive stress as the austempering temperature riseing from 200 to $220^{\circ} \mathrm{C}$, and the surface residual compressive stress increases with the increase of austempering temperature from 220 to $260{ }^{\circ} \mathrm{C}$. The maximum compressive stress is $23.2 \mathrm{MPa}$.

\subsubsection{Residual thermal stress}

The thermal stress is created when there is a change in size or volume and constrained by the temperature change. So determining the distribution of the temperature field is the first step in the study of thermal stress. The temperature distribution of CADI grinding balls with different austempering temperatures by numerical simulation is shown in Fig. 11. It can be seen that the temperature of grinding balls austempered with different temperatures gradually decreases with the increase of time, and tends to be stable. The cooling rates of grinding balls on the surface $(\mathrm{R})$ and at $2 / 3$ radius are significantly higher than that at $1 / 3$ radius and the center $(O)$ for the same austempering temperature. The surface temperature of the grinding ball is mainly determined by the nitrate temperature and heat transfer between the nitrate and the CADI grinding balls. When the CADI grinding ball is immersed in the salt bath, the surface temperature of the grinding ball decreases rapidly. The temperature variation in the center of the grinding ball is attributed to the thermal conduction from the inside to the outside of the grinding ball. It can also be determined that the temperature in the grinding ball decreases rapidly when the holding time is less than $300 \mathrm{~s}$ and slowly when the time is more than $300 \mathrm{~s}$ by comparing the slope of the tangent at certain points of the cooling curves in Fig. 11. When the holding time is over $300 \mathrm{~s}$, the temperature in all parts of the grinding ball is lower than about $400{ }^{\circ} \mathrm{C}$. This proves that the grinding ball entered the range of ausferrite transformation ${ }^{[30]}$. Due to the molten nitrate medium possessing a high coefficient of heat transfer, the temperature of the grinding ball rapidly reduces to the intermediate transformation zone, and improves the hardenability of the grinding balls. 

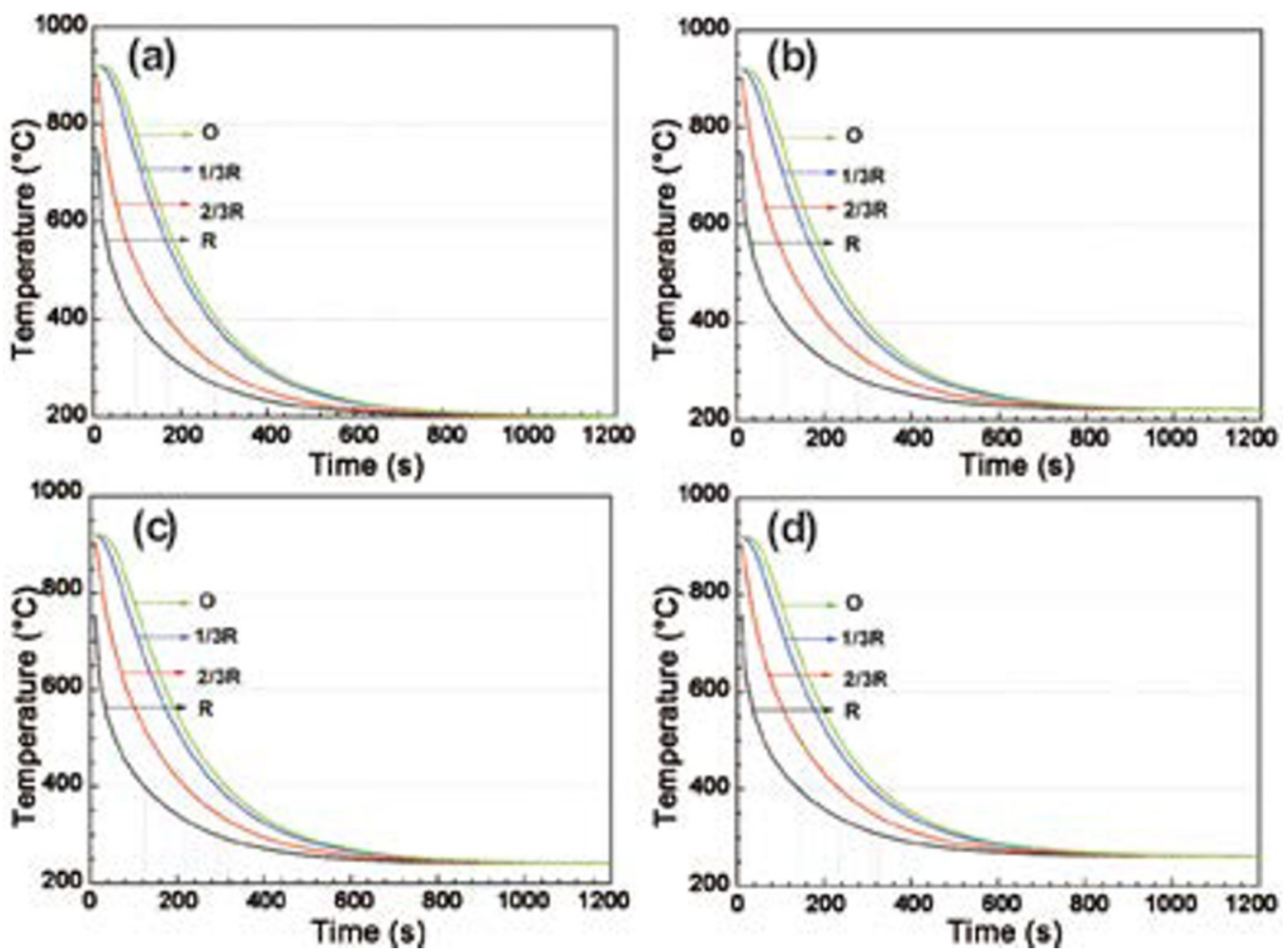

Fig. 11: Effect of austempering temperature on temperature distribution of CADI grinding balls at different regions (a) $200^{\circ} \mathrm{C}$; (b) $220^{\circ} \mathrm{C}$; (c) $240^{\circ} \mathrm{C}$; (d) $260^{\circ} \mathrm{C}$

In addition, the temperature at the same time and same position in the grinding ball increases with the increase of austempering temperature. This means the cooling rate of the grinding ball is lower at a higher austempering temperature (more than $200{ }^{\circ} \mathrm{C}$ ). When the surface temperature on the grinding balls is lower than $575^{\circ} \mathrm{C}$, it can be said that the faster cooling rate, the greater is the temperature differences between the center and the surface of the grinding balls, as illustrated in Fig. 12.

Figure 12 shows the relationship of the variation of the temperature difference between the center and the surface versus the surface temperature of the grinding ball within four austempering temperatures. It can be seen that the temperature difference is the same when the surface temperature is above

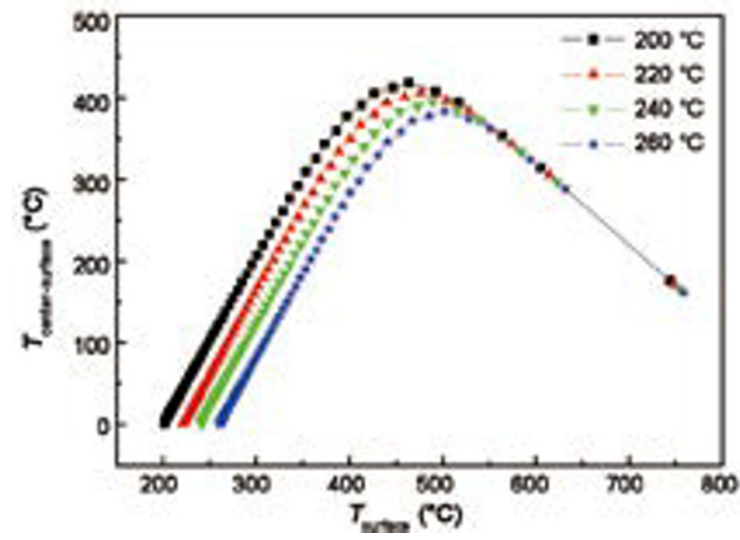

Fig. 12: Variation of temperature difference between center and surface versus surface temperature of grinding ball with different austempering temperatures
$575{ }^{\circ} \mathrm{C}$, and it increases with the decrease of the surface temperature. The maximum value appears at different surface temperatures within the range of $450-500{ }^{\circ} \mathrm{C}$ and it increases with the decrease of the austempering temperature. Then the differences become small when the surface temperature is close to the austempering temperature. It is noticed that the maximum temperature difference value between the center and the surface of the grinding ball happens in the elastic-plastic temperature ${ }^{[31]}$.

The distribution of residual thermal stress within the CADI grinding balls austemped by different austempering temperatures is shown in Fig. 13. It can be seen that the thermal stress in the grinding balls changes from the tension inside part with radius $0-35 \mathrm{~mm}$ to compression outside with a radius of $35-62.5 \mathrm{~mm}$, and the stress balance state presents in spherical face with radius $35 \mathrm{~mm}$. The compressive stress increases with

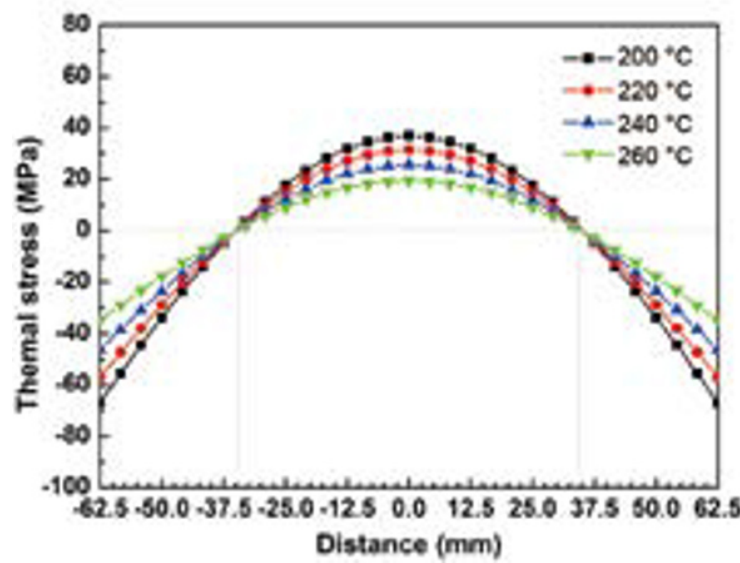

Fig. 13: Residual thermal stress distribution of CADI grinding balls using by numerical simulation 
the increase of radius from spherical face of radius $35 \mathrm{~mm}$ to the surface, and the maximum value appears on the surface. However, the tensile stress decreases with the increase of radius from the center to the radius of $35 \mathrm{~mm}$, and the maximum value appears in the center. When the grinding ball is quenched in the salt bath, the cooling rate of the center part is much lower than that outside. Therefore, the outside part of the grinding ball shrinks more largely than that of the inner part at the beginning. Because of the incompressible character of the metal material volume, the tensile stress in the outside part of ball occurs and leads to deform plasticity. The residual thermal stress at the outside of the grinding ball could be ignored at higher temperatures above $600{ }^{\circ} \mathrm{C}$. When the temperature of the inside part of the grinding ball cools from the high temperature to the austempering temperature, the outside of the ball with low temperature becomes stiff and prevents the shrinkage of the inside part. Therefore, this results in a tensile stress in the center of the grinding ball and a compressive stress in the surface. The detailed differences of residual thermal stress in different austempering temperatures can be explained by the above analysis of the temperature field.

The residual thermal stress on the surface of grinding ball with different austempering temperatures is described in Fig. 14. It can be seen that the surface residual thermal stress decreases with the increase of the austempering temperature. The thermal stress is mainly caused by the temperature gradient inside the grinding ball, and the internal temperature gradient gradually decreases with the increase of the austempering temperature as shown in Fig. 12. Therefore, the surface residual thermal stress in the grinding ball decreases accordingly.

\subsubsection{Surface residual phase transformation stress}

During the austempering process, some of the austenite (fcc structure) may be transformed into acicular ferrite (bcc structure) or martensite (bct structure). The austenite to acicular ferrite transformation is accompanied by an atomic volume expansion of approximately $1 \%$, which can lead to the generation of internal stress during transformation ${ }^{[32]}$, and the austenite to martensite transformation can cause greater volume expansion because of martensite's large specific volume ${ }^{[32]}$. The

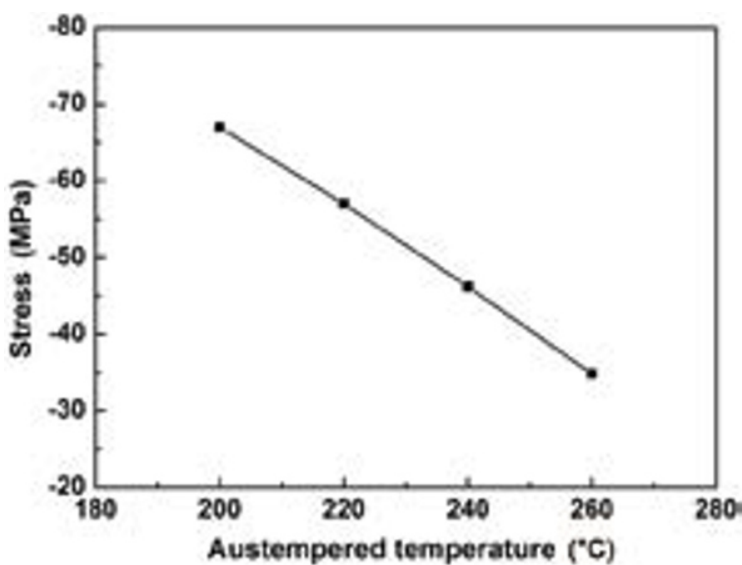

Fig. 14: Surface thermal stress of CADI grinding balls with different austempering temperatures using by numerical simulation technique outside part of grinding ball reaches the phase transformation temperature firstly during the heat treatment process. The outer layer expands and the inner layer still shrinks due to the decrease of the temperature, and the outer layer is subjected to the compressive stress and the inner layer shows tensile stress. When the temperature continues to decrease, the outer phase transformation is completed, and it shrinks as the temperature continues to decrease. Simultaneously, the inner layer expands due to the phase transformation. As a result, the transform stress of the inner part of the grinding ball is compressive, whereas the out layer is tensile stress ${ }^{[33]}$. When the austempering temperature is at $200{ }^{\circ} \mathrm{C}$, the volume fraction of carbon-rich austenite is less and the volume fraction of acicular ferrite is greater, the phase transformation stress is greater than that at higher temperature. The thermal stress in the second heat treatment (tempering of $260{ }^{\circ} \mathrm{C}$ ) stage can be ignored due to the same process parameter and the smaller temperature difference between the tempering and the austempering temperature. Therefore, the transformation stress can be calculated from the measured residual stress and simulated thermal stress according to equation (7), and the results are shown in Table 7. Accordingly, the effect of volume fraction of carbon-rich austenite on surface residual transformation stress of CADI grinding balls is shown in Fig. 15. It can be seen that the surface residual transformation stress is tensile stress, and linearly decreases with the increase of the volume fraction of carbon-rich austenite. The linear regression analysis of the surface residual phase transformation stress and the volume fraction of carbon-rich austenite were carried out, and the slope of the regression equation is -5.03 . This means that, within the range of $18 \mathrm{vol} . \%$ to $31 \mathrm{vol} . \%$ of carbon-rich

\section{Table 7: Surface residual phase transformation stress of CADI grinding balls}

$\begin{array}{cc}\begin{array}{c}\text { Austempering temperature } \\ \left({ }^{\circ} \mathrm{C}\right)\end{array} & \begin{array}{c}\text { Phase transformation stress } \\ (\mathrm{MPa})\end{array} \\ 200 & 80.6 \\ 220 & 42.4 \\ 240 & 28.9 \\ 260 & 11.6\end{array}$

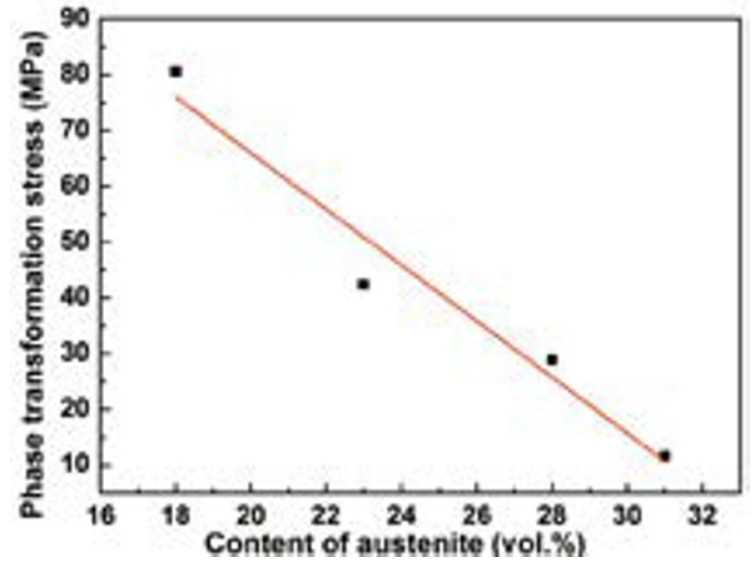

Fig. 15: Effect of volume fraction of carbon-rich austenite on surface residual transformation stress of CADI grinding balls 
austenite, the tangential transformation stress will reduce by 5.03 MPa when the carbon-rich austenite content increases 1vol.\% .

\section{Conclusions}

(1) The distribution of ausferrite structure shows uniform and the amount of white-bright zone (mixture of martensite and austenite) decreases with the increase of austempering temperature. Both the volume fraction and the carbon content of carbon-rich austenite increase with the increase of the austempering temperature.

(2) The surface residual stress is mainly composed of surface residual thermal stress and surface residual phase transformation stress in this work. The surface residual tensile stress only exists at the austempering temperature of $200{ }^{\circ} \mathrm{C}$, and the surface residual compressive stress increases with the increase of austempering temperature from $220^{\circ} \mathrm{C}$ to $260^{\circ} \mathrm{C}$.

(3) The surface residual thermal stress decreases with the increase of the austempering temperature. The thermal stress in the grinding balls changes from the tension at inside part with the radiusof $0-35 \mathrm{~mm}$ to the compression at outside layer with the radius of $35-62.5 \mathrm{~mm}$, and the stress balance state presents at the spherical face with the radius of $35 \mathrm{~mm}$.

(4) The surface residual transformation stress is tensile stress, and linearly decreases with the increase of the volume fraction of carbon-rich austenite. The surface residual transformation stress will reduce by 5.03 MPa accompanied with 1vol.\% increase of the carbon-rich austenite within the range of $18 \mathrm{vol} . \%$ to 31 vol. \% of carbon-rich austenite.

\section{References}

[1] Gates J D, Dargusch M S, Walsh J J, et al. Effect of abrasive mineral on alloy performance in the ball mill abrasion test. Wear, 2008, 265: 865870.

[2] Peng Yuncheng, Jin Huijin, Liu Jinhai et al. Effect of boron on the microstructure and mechanical properties of carbidic austempered ductile iron. Materials Science and Engineering A, 2011, 529: 321-325.

[3] Cardoso P H S, Israel C L, Strohaecker T R. Abrasive wear in austempered ductile irons: a comparison with white cast irons. Wear, 2014, 313: 29-33.

[4] Laino S, Sikora J A, Dommarco R C. Development of wear resistant carbidic austempered ductile iron (CADI). Wear, 2008, 265: 1-7.

[5] Han C F, Sun Y F, Wu Y et al. Effects of vanadium and austempering temperature on microstructure and properties of CADI. Metallography, Microstructure, and Analysis, 2015, 4: 135-145.

[6] Sun Xiaoguang, Wang You, Li Dongyang et al. Modification of carbidic austempered ductile iron with nano ceria for improved mechanical properties and abrasive wear resistance. Wear, 2013, 301: 116-121.

[7] Peng Yuncheng, Jin Huijin, Liu Jinhai et al. Influence of cooling rate on the microstructure and properties of a new wear resistance carbidic austempered ductile iron (CADI). Materials Chracterization, 2012, 72: 53-58.

[8] Liu Jinhai, Wang Kunjun, Li Guolu et al. Development and Trends of CADI in domestic and abroad. Modern Cast Iron, 2015, (6): 40-45. (In Chinese)
[9] Benam A S. Effect of alloying elements on austempered ductile iron (ADI) properties and its process: Review. China Foundry, 2015, 12: 54-70.

[10] Kumari U R, Rao P P. Study of wear behaviour of austempered ductile iron. Journal of Materials Science, 2009, 44: 1082-1093.

[11] Akbarzadeh Chiniforush E, Rahimi M A, Yazdani S. Dry sliding wear of $\mathrm{Ni}$ alloyed austempered ductile iron. China Foundry, 2016, 13: 361-367.

[12] Hsu C H, Chuang Taoliang. Influence of stepped austempering process on the fracture toughness of austempered ductile iron. Metallurgical and Materials Transactions A, 2001, 32A: 2509-2514.

[13] Yang Jianghuai, Putatunda S K. Improvement in strength and toughness of austempered ductile cast iron by a novel two-step austempering process. Materials Design, 2004, 25(3): 219-230.

[14] Akbarzadeh Chiniforush E, Iranipour N, Yazdani S. Effect of nodule count and austempering heat treatment on segregation behavior of alloying elements in ductile cast iron. China Foundry, 2016, 13: 217-222.

[15] Fu Binguo, Li Zhuoqing, Zhao Xuebo et al. Formation mechanism of spheroidal carbide in ultra-low carbon ductile cast iron. China Foundry, 2016, 13(5): 346-351.

[16] Noguchi T, Shimizu K, Takahashi N et al. Strength evaluation of cast iron grinding balls by repeated drop tests. Wear, 1999, 231: 301-309.

[17] Camurri C, Carrasco C, Dille J. Residual stress during heat treatment of steel grinding balls. Journal of Materials Processing and Technology, 2008, 208: 450-456.

[18] Sinha V K, Godaba V S. Residual stress measurement in worked and heat treated steel by X-ray diffractometry. Materials Science and Engineering A, 2008, 488: 491-495.

[19] Cheng Weili, Finnie I, Gremaud M et al. Measurement of near surface residual stresses using electrical discharge wire machining. Journal of Engineering Materials and Technology, 1994, 116: 1-7.

[20] YB/T 5338-2006. Retained austenite in steel-Quantitative determinationMethod of X-ray diffractometer. Standards press of China, 2006.

[21] Daber S, Rao P P. Formation of strain-induced martensite in austempered ductile iron. Journal of Materials Science, 2008, 43: 357-367.

[22] Romanov V A, Lazarev E A, Khozeniuk N A. The evaluation of the stress-strain state for the cylinder heads of high-powered diesel engines using the multiphysics Ansys technology. Procedia Engineering, 2015, 129: 549-556.

[23] GB/T 24733-2009. Austempered ductile iron (ADI) castings. Standards Press of China, 2010.

[24] Yang Zhaoyu. Research on new heat-treatment technology and failure mechanism of CADI grinding ball. Master diss., Hebei University of Technology, 2011.(In Chinese)

[25] Rossini N S, Dassisti M, Benyounis K Y et al. Methods of measuring residual stresses in components. Materials Design, 2012, 35: 572-588.

[26] Liu shengfa, Chen Yang, Chen Xin et al. Microstructures and mechanical properties of helical bevel gears made by $\mathrm{Mn}-\mathrm{Cu}$ alloyed austempered ductile iron. Journal of Iron and Steel Research, International, 2012, 19(2): 36-42.

[27] Meier L, Hofmann M, Saal P et al. In-situ measurement of phase transformation kinetics in austempered ductile iron. Materials Characterization, 2013, 85: 124-133.

[28] Basso A, Martinez R, Sikora J. Influence of chemical composition and holding time on austenite( $(\mathrm{Y})$-ferrite $(\alpha)$ transformation in ductile iron occurring within the intercritical interval. Journal of Alloys and Compounds, 2011, 509(41): 9884-9889.

[29] Chou J M, Hon M H, Lee J L. The austenite transformation in ferritic ductile cast iron. Materials Science and Engineering A, 1992, 158(2): 241-249.

[30] Panneerselvam S, Putatunda S K, Gundlach R et al. Influence of intercritical austempering on the microstructure and mechanical properties of austempered ductile cast iron (ADI). Materials Science and Engineering A, 2017, 694: 72-80.

[31] lannitti $G$, Ruggiero $A$, Bonora $N$ et al. Micromechanical modelling of constitutive behavior of austempered ductile iron (ADI) at high strain rate. Theoretical and Applied Fracture Mechanics, 2017, 92: 351-359.

[32 Bhadeshia H K D H, Honeycombe R W K. Steels: microstructure and properties. Third edition. Oxford, 2006: 1-337.

[33] Panneerselvam S, Martis C J, Putatunda S K et al. An investigation on the stability of austenite in austempered ductile cast iron (ADI). Materials Science and Engineering A, 2015, 626: 237-246. 